\title{
EFFECTS OF DICTOGLOSS ON NON-ENGLISH MAJORED UNDERGRADUATES' LISTENING COMPREHENSION
}

\author{
Ngo Thi Minh Hai*, Le Duc Hanh \\ Faculty of Foreign Languages, Hanoi University of Industry
}

Received 12 January 2020

Revised 10 March 2020; Accepted 30 May 2020

\begin{abstract}
Listening has long been considered a hard-to-deal skill for both ESL teachers and learners. Although there are abundant studies on this field aiming to diversify in-class listening activities and make them more efficient for learners, the demand for one which manages to provide or reinforce necessary linguistic knowledge for students is still high. This action research was conducted with 40 pre-intermediate non-English majored students through three qualitative methods including focus group interview, teacher's diary and artifacts to examine the effects of dictogloss on listening comprehension in English teaching and learning process and to explore the learners' attitudes towards this practice. Findings of the study were that dictogloss helped to improve the learners' listening comprehension through activating and raising their awareness of linguistic knowledge and providing them a clear context for listening, which also made them more interested in the activity.
\end{abstract}

Keywords: action research, dictogloss, listening comprehension, linguistic knowledge

\section{Introduction}

In some Asian developing countries like Vietnam, education is paid a lot of attention; it is considered a key to success in life. A person with high qualifications is much appreciated in the society, which also means certificates are sometimes considered more important than competences or skills (Le, 1999). That fact results in the purpose of learning, which may be for passing exams or getting certificates. Besides, Vietnamese students are often complained to be lazy and passive, which is believed to be the consequence of following Confucianism, in which a teacher plays a dominant role in class, he or she is expected to organize and assign tasks in the classroom whereas students are expected to keep silence and go after their teacher's instruction.

In order to enhance national English language competency, Ministry of Education and Training in Vietnam has implemented Project 2020. The project once again emphasizes the important role of English for Vietnamese learners. For non-English majored students, this means a lot when they have to reconsider their way of learning English because now, they are not only tested in written exams with lots of grammar, reading and writing exercises but speaking and listening as well. The importance of listening has been discussed among various studies. According to Hedge (2000), in communication, we spend $9 \%$ of our time on writing, $16 \%$ on reading, $30 \%$ on speaking and $45 \%$ on listening. This skill is particularly significant in the context of Vietnam where the teaching and learning of listening has still been neglected for years.

At the author's institution, most students are non-English majored coming from all parts of the country and majoring in technical fields. All of them have studied English for at least 7 years since primary school, but many of them are from rural areas where they rarely have a chance to speak and listen in English. 
At university, the students have to study English for 6 semesters from elementary to achieve level B1 according to CEFR-V, a Vietnamese version of the Common European Framework of Reference for Languages. The research was carried out with 40 non-English majored students at pre-intermediate level during 10 weeks with 5 listening lessons at semester 3 . The participants are from 18 to 20 years old, including seven male and thirtythree female students. The students have two English lessons every week, and each lesson is taught with one language skill for two contact hours. The researcher-teacher has been teaching English for more than 10 years, and she also has much experience working with non-English majored undergraduates.

The study is conducted on the theoretical framework of the learning and teaching of listening and the theory of dictogloss, which will be justified in the literature review. The rationale for choosing dictogloss to improve listening comprehension is because of the problem arising in the researcher's context and the advantages of dictogloss. In the author's listening class, there are often three main parts: pre, while and post-listening; due to the scope of this study, only pre- and post-listening stages are mentioned. In the pre-listening step, the common activities for students are describing pictures and answering some topic-related questions, or matching words with pictures or definitions. After these activities, students are expected to be activated with background knowledge or provided with some vocabulary about what they are going to listen. However, as the researcher observed, most of the time, the students still cannot use or even recognize the new words in the whilelistening step. Hence, in this case, linguistic knowledge is not provided effectively. Besides, in post-listening activities, students are often given some noticeable structures in the listening text and practice with speaking or writing skill. Students repeat the structures mechanically and they soon get bored with that. Hence, the teacher usually skips or makes this step the homework exercise. Meanwhile, according to Hedge (2000), the post-listening activity is important for reinforcing students' understanding about the text through investigating language features deeply. Consequently, as noted by the teacher, rhetorical knowledge is not sufficiently and effectively provided through both steps of pre- and post-listening, which may result in students' poor performance in while-listening process. For that reason, dictogloss is expected to address the problem with its advantages in promoting students' awareness of linguistic features, cooperative learning and giving them a clear objective as well as context for listening (Wanjryb, 1990; Vasiljevic, 2010; Smith, 2012). This study is conducted to answer the research question:

How does dictogloss affect non-English majored undergraduates' ability of listening comprehension regarding linguistic knowledge?

\section{Literature review}

\subsection{Listening comprehension}

Listening comprehension is a complex process involving types of knowledge, which are classified as in-speech and in-head knowledge (Hedge, 2000). Hedge (2000) explained that in-speech knowledge refers to knowledge of language and acoustic signals, which are available in the speech to comprehend what is presented whereas inhead knowledge implies the listener's general world knowledge or prior knowledge. These types of knowledge are also known as two common approaches in the teaching and learning of listening comprehension, which are bottom-up and top-down process (Hedge, 2000; Nunan, 1997; Richards, 2008). In bottom-up approach, listeners use linguistic knowledge in the text to construct meaning. Specifically, Nunan (1997) explained the rule of this process as follows: from the smallest linguistic unit like phoneme, the listener links it together to form words; grouping words he/ 
she forms the meaning of a phrase, and linking phrases the listener understands utterances; then utterances form the whole meaning of the text. Consequently, understanding comes in the end after the listener utilizes what he/ she can hear from the text itself. Nevertheless, with each topic, the ability for listening comprehension changes due to each listener's background knowledge. As a result, the other approach is named top-down process. In this one, the listener brings his/her own prior knowledge to the text to make sense of it. The real listening stage is to confirm what he/she is expected in advance and adds more detailed information if there is (Richards, 2008). However, there is a concern that when listening, which approach will the listener use? Scrivener (2005) explained that in a real listening process, the listener consciously or unconsciously applies both approaches, in which the linguistic and background knowledge interact with each other to support the listener to comprehend the input. That is called an interactive approach. Based on the process of listening, three steps of teaching listening have been introduced in class for ages with pre-, while- and post-listening. In the scope of this study, only pre- and postlistening steps are taken into consideration. As Hedge (2000) stated, the function of pre-listening stage is to assist the listener to contextualize the speech, provide him/her with a clear purpose for listening and help $\mathrm{him} / \mathrm{her}$ to predict or give out any hypothesis of the coming input. Adding to the point, he said that pre-listening should also activate and/or provide the listener with background knowledge for the topic as well as introduce vocabulary that he/she may not know. Sharing this point, Richards (2008) confirmed that the activities in pre-listening serve the purpose of preparing the listener with bottom-up and topdown approach. Meanwhile, post-listening step helps students to have a more intensive look into the text (Hedge, 2000). Students may be asked to discuss or give their reflective thinking about the topic or if there is any part they need to clarify, the teacher will go back and analyze the text in more detail, in which the bottom-up process is practiced.

\subsection{Dictogloss in listening comprehension}

Dictogloss was first presented by Wajnryb (1990). This activity originated from dictation; however, it makes up for the drawbacks of its predecessor for a rote teaching method, in which the learners merely note down teacher's reading without thinking anything (Jacobs \& Small, 2003). In order to simplify the term, the researcher adopts a definition of Newman (2012), which divided "dictogloss" into two parts: "dicto" means dictation and "gloss" is equal to paraphrase or interpret the text. Thus, unlike traditional dictation, dictogloss requires the learners to revise the text as long as the original meaning is kept. Concerning the process of dictogloss, many researchers suggested some slightly different ones; however, in this study, the researcher follows the original process proposed by Wajnryb (1990), which have four steps:

a. Preparation: The teacher provides some key vocabulary and introduces the topic.

b. Dictation: The text is read twice at normal speed. At the first time, the learners are required to do nothing but listen to get the main ideas of the text. At the second time, they are allowed to take notes.

c. Reconstruction: The learners work in groups to compare their notes and build up a new version of the text provided that they keep the meaning close to the original one.

d. Analysis and correction: The learners compare the reconstructed text with other groups' or with the original text to make any correction.

Dictogloss is beneficial to the teaching of listening comprehension in the following ways. First and foremost, dictogloss raises students' awareness of linguistic knowledge (Vasiljevic, 2010). In the reconstruction step, the learners use their notes and discuss with their friends how to reproduce the text. Through this, they have a chance to consider 
the text more intensively, they link each word in the notes to make sentences and form a meaningful text. Besides, by taking notes and discussion, the listeners can practice some new words explicitly in both written and spoken forms; thus, the vocabulary is acquired effectively. Moreover, when reconstructing the notes, the learners have to rearrange ideas in a logical way. Then in the last step of analyzing and correcting, they have to compare their reconstructed text with other groups' or with the original text carefully to find any differences. Hence, through this process, they self-notice and self-realize rhetorical patterns and language features in the target language (Shak, 2006). Second, dictogloss promotes collaborative learning among learners. In traditional listening class, the learners work individually most of the time; however, with dictogloss, they have a chance to cooperate with their group mates. Collaborative learning enables the learners to freely express themselves, collect more ideas from people with different background knowledge, and reduce the workload (Burdett, 2003). Especially in listening skills, collaboration helps the listeners propose more hypotheses to understand the text without hesitation when they only have to speak in their small group. Third, dictogloss provides the learners with a clear purpose and context for listening (Vasiljevic, 2010). Dictogloss is a meaning-based activity, in which the learners reproduce the text based on what they listen. They cooperate with friends to work out the meaning and have a reconstructed version in the end. The learners are actively engaged in this process rather than only listen and do exercises like in traditional listening class. Thus, listening becomes more interesting.

\section{Research Method}

To begin with, action research methodology is taken into consideration. Action research was developed by Kurt Lewin in 1940s in the United States. Since then, this methodology has been widely applied in social sciences as well as education in many undergraduate and graduate courses (Price, 2001). To define the term, Hinchey (2008) stated clearly that action research is an on-going process of systematic examination where the same steps are conducted repeatedly by a community insider; its purpose is to make some changes or innovation that improves the current situation. The on-going or cyclical process of this methodology varies according to different researchers. Besides, one thing that makes action research different from traditional research is the researcher is not the outside experts but the community insider like classroom teacher. That enables the researcher to investigate problems arising from his/her own context and brings about the change to the situation of the researcher, which he/she believes to be important. Thus, the result of an action research cannot be generalized; it is not true for every circumstance and merely applicable in the research's one. However, action research is now a preferable model because its aim is to bring about the change in some community or program; it can tell each individual teacher the best solution to his/her specific case at an exact moment (Hinchey, 2008). Hence, owing to the aim and the advantage of action research, this study applied this methodology to investigate the problem in the researcher's classroom and find out a solution to improve the situation.

In this study, the researcher followed qualitative methodology for the following reasons. Firstly, qualitative methods enabled the researcher to have a better understanding of how and why the innovation worked and did not work. Specifically, they helped to focus on the investigation of participants' attitude, perspectives, preference and thought in the context (Harwell, 2011). Secondly, for a small-scale study like this with only 40 students, qualitative methodology was more appropriate to be employed. Finally, qualitative method was chosen because of its inductive style. This means the researcher 
would develop any theories or ideas of the innovation after collecting data from her participants rather than start with fixed ones before the data is collected (Becker \& Bryman, 2004; as cited in Dahlberg \& MacCaig, 2010). In this study, with the research question: "How does dictogloss affect non-English majored undergraduates, ability of listening comprehension regarding linguistic knowledge?", the author did not wish to grow any theories fixed in advance but through the data she wanted to know whether and of what aspects dictogloss could improve the current problem in her listening class. In this research, three data collection instruments were employed, which were focus group interview, teacher's diary and artifacts.

\section{Focus Group Interview}

Focus group interview was chosen because it enabled the researcher to investigate indepth information of the participants' thought, attitude and opinion about a particular issue through their communication (McLafferty, 2004). Focus group was beneficial as the participants follow their peer's answer and had more thought than in other kinds of oneto-one interview (Webcredible, 2006). In this study, focus group interview was employed to collect data about the participants' attitude and opinion after dictogloss was applied in their listening class. The interview was carried out at the end of the course with four representative groups; each group involved seven students with different study ability and from mostly dissimilar groups in dictogloss activity. The reason for choosing diverse interviewees was because this enabled the researcher to get rich sources of data from different points of view when the participants were encouraged to talk more than in the same old group. Each group interview lasted for about one hour and the researcher was also the moderator. In order to capture all responses, she audio-recorded the interview; besides because focus group is advantageous for the researcher to know about the participants' attitude and behaviour through discussion, the researcher decided to note down any important occurrences and observation as well. The interview questions were adapted from Shak (2006) with his attitude questionnaire. In the interview, the participants were allowed to use Vietnamese if they wish to in order to express themselves clearly because they were just at pre-intermediate level and more importantly, the purpose of the interview was not testing their English speaking competence. Data from focus group interviews were transcribed and categorized into different themes namely Students' engagement, Students' awareness of linguistic knowledge and Students' ability of listening comprehension; then the themes were sorted to make any relationship among categories basing on literature.

Artifacts

Artifacts were used in this study to collect data about the participants' variations in work, which informed the researcher about their learning progress or any difficulties when they comprehended the text. Both students' individual notes and groups' notes were collected. Students' individual notes were used to compare with theirs in the previous lessons with dictogloss to see whether each individual could make progress in comprehending the text or whether they could improve their note taking skill in listening comprehension, particularly, their ability to realize and note down key vocabulary and information. Groups' notes were collected to compare with the listening script, which was divided into smaller main parts according to several main criteria, including the ability to realize verb tense and key vocabulary to form sentences, and the awareness of key discourse markers and rhetorical patterns. Each criterion was rated at three levels: not aware, partially aware and fully aware, which was adapted from Smith (2012). In analysis step, any mistakes that did not cause content misunderstanding would not be counted because the focus of the activity is checking 
comprehension. Both students' mistakes and success in comprehending the text should be noted with the same criteria in dividing the script to find reasons for their progress or difficulties. For example, one group was able to be aware of key vocabulary and text structure; however, they used wrong verb tenses, which led to misunderstanding of the text. All of that was noted down carefully.

\section{Teacher's Diaries}

Explaining the term, Moon (2006) said diary is a collection of the writer's reflective thinking such as questions, comments, analyses, or tentative justifications for something... Adding to the point, Hinchey (2008) stated that diary is used as a means of reflection, which helps to record what happens in one's professional life. Diary is a widely used method because it is cheap and easy to be conducted but can help to collect rich sources of data. This qualitative data collection instrument was employed in the study to record the teacher-researcher's reflective thinking about the participants' engagement and ability to understand the text throughout the innovation. Besides, data from the teacher's diaries was also exploited to triangulate data from group interview and artifacts. Initially, observation method was intended to be used; however, as it took time for the teacher to both handle group discussion and observe, teacher's diary was more advantageous when most of the time, the teacher-researcher just needed to note down her thoughts at the end of the class. To keep her thoughts, the researcher used the combination of both structured and unstructured diaries in which there are three criteria: The participants' engagement, The participants' ability to understand the text and Others. The column "Others" was for noting down any occurrences or immediate thoughts of the researcher while the activity was implemented. Each diary was written after every lesson with dictogloss and all diaries were looked back in the end for reflection. Teacher's diaries were kept in narrative form which were also put into various themes and enabled the researcher to analyze under the same code tree. These data were also used to triangulate data from interviews and the students' artifacts.

\section{Results}

After analyzing data, the following sections present key findings of the research.

\section{Students' Engagement}

The data showed that most students were engaged in the activity enthusiastically. One student answered in group interview, "The thing I liked most in this activity was that we had a chance to work in group, I was so eager to share notes, discuss, even argue and fight for my opinion" (Interview 2, Student A). Through the researcher's observation and interview, not only strong students but the weak ones got involved much in group discussion. Some weak students stated that they were interested in discussing in their group despite their less contribution than others. Explaining to this, one said, "I could not take much note and my vocabulary was limited but I didn't care much. I still enjoyed group work because while my friends were discussing, I could check my notes and my understanding of the text, I could learn much from that" (Interview 2, Student B). Another student in the same group with her added, "Although she took little note, her role was really important because with some new words that we did not know, she transcribed into Vietnamese, which we based on to find out the words later" (Interview 2, Student C). This was confirmed when the researcher looked at the students' individual notes, in which many of them unconsciously jotted down the words, made spelling mistakes and used Vietnamese, for examples, "I really thing that...", "make the heart bit fast...", "me tro po li tần" (Vietnamse transcription of "metropolitan"). It was clear that group work provided the students with a comfort 
zone to express themselves fully and freely, which stimulated them to share more and give out more hypotheses to comprehend the text. Moreover, another student commented, "I liked working with other students, if I missed any information, there would probably be someone in my group who did not, and I could learn from group discussion. Besides, it also helped me to show off what I'd known. Group work enabled us to share the workload." (Interview 3, Student A). This comment was shared by many other students in group interviews. Also, the students got involved in group work because they thought it was beneficial to them in learning.

Unlike usual listening activity, dictogloss brought about a new atmosphere, in which the participants had a chance to interact with others rather than working individually. One more factor that motivated the students is the competitiveness of the activity. In analysis step, each group compared their text with the others' or with the original one and they always tried to win over the other groups. In teacher's diary 2, it was recorded: “Group 1 made many mistakes. There was a small argument among these group members after the teacher corrected their text. It seemed like they thought they could do better. Some members felt upset when other groups could reconstruct the text but they could not. One member even asked the teacher to do dictogloss one more time immediately!"

Despite the participants'greatinvolvement, it was obvious that there was time they did not get really engaged in the activity. In teacher's diary 1 , it was noted, "The text seemed to be easy, students collected all notes and just one member worked, he/she wrote a new note for the group". Besides, the topic of the text may also limit students' involvement. Answering in the interview, one student said, "I think the topic of dictogloss number 3 was difficult, I was not familiar with it, I did not know much about housing and living conditions of working people in the past. Even I can hear all single words but I could not understand the meaning. So I discussed less". Meanwhile, as cited in the teacher's diary 3 , the overall class engagement was lower than in the previous classes, which meant that the background knowledge for some specific topics might limit some learners' involvement in the activity. Besides, the participants' understanding of the activity instruction also affected their engagement. Teacher's diary 1 and 3 noted some points, "Some students were reluctant in group discussion because they thought they had taken notes and given them to their group leader to write, that was enough." Or "Some students thought it was not necessary to work out some new words, provided that they still got the meaning of the text so they let go and did not try their best."

\section{Students 'Awareness of Linguistic Knowledge}

Another positive finding through the application of dictogloss was that the students were better aware of linguistic knowledge, especially vocabulary, grammatical structures, rhetorical patterns, and discourse markers. Answering in the interview, many students shared the same point that this activity was very helpful for them to learn vocabulary. One student said, "Compared with normal listening text, the text in dictogloss did not have many new words, however, it made me memorize the words much easier because when I listened, I heard the sound, noted it down, then we spoke it out, even repeated the sound many times in group discussion to find the exact word and wrote it again. After this, I remembered how to pronounce and write the new word better than the usual way of learning vocabulary" (Interview 4, Student A). Another added, "When reconstructing the final text, we considered the part of speech very carefully to make the sentence not only meaningful but also grammatically correct. When taking notes, we often did not write down the full form of the word, maybe just its abbreviation or symbols, so we needed to discuss to put the right word in the right place, for example, following a normal verb should be an adverb and after 
the verb "to be" should be an adjective...." (Interview 4, Student B). Besides vocabulary, the students also pointed out that dictogloss enabled them to activate and be more aware of grammatical structures, as one said, "I remember one lesson with dictogloss, I heard of the verb "house" in the sentence, and one member in my group made sure that she noted "had to be" before "house", that reminded me of the passive voice. Some argued that there should not be "to be" in front of a normal verb but because I knew it for sure, then I talked to them about passive voice, and so this phrase should be "had to be housed" and they were convinced when we looked back at the text content." (Interview 1, Student A). In addition, through the researcher's observation during group discussion, it was noted, "Students were aware and knew how to note some discourse markers such as: but, despite, however, as a result... and then based on those to reconstruct the meaning of the text. I could listen to group 3 discussing, one student said he had the word "but", so it meant the meaning of two sentences linked by "but" were opposite". (Teacher diary 4). Hence, it could be concluded that the linguistic knowledge gained or activated during the activity did support the listeners to work out the text meaning better by making sense of the sounds to find words and linking words to understand relationship among sentences.

Although the students' awareness of those linguistic factors was improved, they still did not notice much about the verb tenses. Data from artifacts showed that verb tenses were not used properly even the learners could realize some adverbial phrases of time. For example: "At the beginning of the century, living conditions with majority of working people in East London are basic..." or "I was born in England, but I had lived in Germany for the past 20 years. I had arrived in Berlin for 4 years. Before that, I lived in Bonn for 6 years..." (Groups' artifacts). Even though mistakes related to verb tenses appeared fewer in the following lessons, it was clear that the students hardly looked at the text as a whole, i.e. they were still passive in learning. When the text was read, some signals of verb tenses might not be very clear or the students did not have enough time to take note of those inputs, then in group, they merely discussed and linked what they had in the notes to make sentences. This point was noticed by the researcher so that she can clarify the instruction and regulate group discussion better.

\section{Students' Ability of Listening Comprehension}

Besides the finding that linguistic knowledge activation resulted in students' better listening comprehension, one more noticeable discovery about the participants' ability to understand the text was that they could base on the context to reconstruct the meaning. For example, the students knew how to link the sound of the word they heard with the topic or some surrounding words to find the meaning. One student said, "When coming up with a new word, I transcribed its pronunciation and, basing on that, in group we looked up in the dictionary to find which word had the meaning that matched the context". Another added, "Sometimes, we could also lean on the surrounding words to guess the new word, for example, we could note "the poor and needy/ nitde", at first we were not sure about the word "needy" or "nitde" but because it was linked with "the poor" by "and", so it must have the same meaning with "the poor", then we checked it in the dictionary." (Interview 1, Student B). Many other students shared the same point and it was understandable that dictogloss provided the learners with a clear context to help them comprehend the content more easily than usual listening exercises which merely have one or two sentences in the instruction to introduce the context. Besides the advantage of a context-based activity, the participants thought that dictogloss was also beneficial to listening comprehension because it supported them to realize key words and 
main ideas. Some comments collected from group interviews were, "It was an effective way to study listening because I could get the main content from some key words", or "It helped me to be more focused on listening and sharpened my skill of realizing key words" or "It was useful for me to detect, note down key words and understand the main content to do exercises like True/ False".

Through interviews, most participants believed that their listening comprehension skill was enhanced from dictogloss because thanks to it, they could know how to note down key words to comprehend the text. However, data from artifacts showed some difference. The students' individual notes were looked at and what noted were not key words but any words that the students could jot down, from which each individual could hardly base on to reconstruct the text. For example, one students' note was, "At the beginning century, very basic, living condition, rather than, houses were, has to be houses..." or "At the beginning of, living condition for major in East London was basic, how this world crowded and usually very badly..., because there was no...". Another matter relating to students' individual notes was that they tried to write down full sentences while there may not be sufficient time for them to do so. Consequently, they were likely to miss the next one because the teacher did not wait for them to complete a sentence to read the followings. Hence, data from individual notes indicated that most students did not know how to note down key words, and they just tried to write as much as possible.

Despite the participants' poor notes, groups' artifacts confirmed that every group could understand main ideas from the text. Even though they still made some grammatical mistakes, the major content was conveyed, which was all that listening comprehension required for. There were two reasons for this. Firstly, although each note was not good, when they shared the notes, they could make up for the missing part in their friends' to make a better one. Secondly, at the first time of listening, the students might get the main idea of the text, so in discussion they might both use notes and their short-term memory to recall the content.

In short, the awareness of linguistic knowledge, a clear context, group work and short-term memory were elements from dictogloss activity to help the students comprehend the text while their ability to take notes of key words was still weak.

\section{Reflection and suggestions}

In this part, the research will be evaluated according to the factors that made dictogloss effective or not; besides, some problems arising during the process of applying dictogloss will be discussed for further study.

Firstly, dictogloss enabled the participants to engage in the activity. The result of students' high engagement was also confirmed in previous studies such as Shak (2006) and Harwood (2008). The reasons for this were because of group work and the newness and competitiveness of the innovation. While group work provided a free environment for the learners to give out their opinions without hesitation and stimulated them to share more, the innovation also brought about a new atmosphere, in which the students try to compete with others for the best reconstructed listening product. Another factor that contributed to the effectiveness of using dictogloss in the context is the choice of texts. Initially, texts were chosen from listening books at the same level of the students; however, the researcher realized that the students found it easy and did not engage much in the activity, because they were familiar with their teacher's voice and her speed of reading the text was somehow much easier to catch up with than in the recording. Then, the researcher decided to change the level of difficulty to " $i+1$ " as Krashen put it (1982; cited in Kidd, 1992). This did improve the students' engagement in 
the next lesson with dictogloss. The teacher's diary 5 noted, "The text this time was more difficult, which encouraged discussion more and students gave out more hypotheses. They worked together sentence by sentence to find out the text meaning". One noticeable finding in this theme was that their low language proficiency did not prevent weak students from engaging in the activity. Another reason to increase student engagement in group discussion is because of the research's context, in which there were only 20 students in each class and they had more than 10 weeks studying together from elementary level; thus, they were quite close and open to each other. This made them more confident when working in groups. Besides, before enrolling in the course, all students were required to take a placement test; hence, their English level was somehow similar to each other. Even there were still some who were not as good as others but in general, they were all at pre-intermediate level, which contributed to the success of the intervention. However, although weak students were eager to join group discussion, they had fewer chances to talk because they could not take as much note as others. Despite the fact that most students enjoyed the activity, there were some having low involvement in discussion, it was because of their understanding of the instruction and the topic of the text as explained above.

Secondly, through dictogloss, the students' awareness of linguistic knowledge was improved much because the students could activate their knowledge and through the process of self-realizing and self-correcting, they could memorize the information much better than in a normal listening activity. In order to carry out dictogloss successfully, it is necessary that the participants be at a certain level of English so that they have something in their mind in advance to share with friends and they can activate something from what they have learnt. Thus, in this research, one factor that made the technique work was that the students were able to help each other in learning and they could actually make up for the part that their friends were missing. Besides, the researcher realized that analysis step played an important role in making the learners aware of linguistic knowledge when they had chance to check the text sentence by sentence. The activity would not have been so effective if in this step, they had just read their version out rather than written it on the board. In the first lesson with dictogloss, the students read out their rebuilt texts to save time and it was recorded: "When one was reading, the others were busy completing their text or chatting to wait for their turn. Only when the teacher asked the student to repeat one sentence or phrase which she thought contained some mistakes, did the rest of the class pay their attention to." (Teacher diary 1). Although rewriting the text took more time than reading, in the researcher's observation, it was more beneficial for the learners; they could analyze grammatical features more carefully, which made them self-aware of the mistakes. Thus, from the second lesson, the students were asked to write their texts on the board. In the mean time, the main reason for the students' being unable to put the verb tense correctly was their passive learning, which is the consequence of the teacher-centered class model remaining in Vietnam for years. In this model, the teacher is supposed to organize and assign tasks to students, who are always expected to follow their teacher's guide. Although in Vietnam, learner-centered class was introduced and it has been already applied, the mind-set of teachers and learners about this has not been improved much.

Thirdly, the prominent advantage of dictogloss was that it was a context-based activity; thus, it provided a clear context for the participants and supported them in the comprehension process. The first time of only reading enabled the students to concentrate $100 \%$ on listening and got general meaning of the text. Most students agreed that listening without doing anything at the same time enabled them to comprehend the information 
much easier. Later, in group discussion they utilized their notes together with what they could remember when listening to reconstruct the text. Analyzing the students' products, the researcher realized that they could convey the main ideas of the text, which was in the same line with Husseinali (2011) when in his study, he found out that dictogloss enabled his students to get main ideas rather than listen to details. However, some students did not know how to take notes properly. When listening, they might realize key words; however, when taking notes, they just jotted down as much as possible. Students might find it difficult to understand their notes later because in fact, they did not have enough time to note much and did not know what to note. Thus, poor note-taking skill may prevent the students from having better reconstructed texts.

Another important factor leading to the effectiveness of dictogloss was that there was enough time available to implement it. As stated above, dictogloss contains four steps; thus, it requires substantial amount of time to be carried out. In the research's context, each listening lesson lasts for 2 hours and thanks to the fact that the syllabus is flexible, the teacher is allowed to spend one first hour covering one unit in the text book. In the other one, she could find supplement exercises or activities to improve the students' listening ability. Hence, dictogloss was often conducted in one hour after the class finished the text book.

\section{Conclusion}

In a nutshell, dictogloss was advantageous in improving the students' listening comprehension through activating and raising their awareness of their linguistic knowledge and providing them with a clear context for listening, which also made them more interested in the activity. However, some arising problems and factors that affected its effectiveness should be considered for future study to ensure equal benefits for all students. Although the technique was carried out in a short period of time, it brought about advantages for the students in listening comprehension and changed their mind as well as their teacher's mind about the learning and teaching of listening. Because of the above values, the researcher expects to be able to expand this activity widely so that all students at her institution can benefit from it. Throughout the process of conducting the study, by instructing and reflecting in every lesson, the teacher has realized the important role of innovation and action research in improving her teaching, which encourages her to learn more and apply more teaching methods to benefit the students.

\section{References}

Burdett, J. (2003). Making groups work: university students' perceptions. International Education Journal, 4(3), 177-191.

Dahlberg, L., \& McCaig, C. (2010). Practical Research and Evaluation: A Start-to-Finish Guide for Practitioners. Sage Publications.

Harwell, M.R. (2011). Research design: Qualitative, quantitative, and mixed methods. In C. Conrad \& R.C. Serlin (Eds.), The Sage handbook for research in education: Pursuing ideas as the keystone of exemplary inquiry (2nd ed.). Thousand Oaks, CA: Sage.

Harwood, C. (2008). A Classroom Experiment: Using dictogloss. Retrieved from http://nus.academia.. edu/chrisharwood/Papers/280592/A_Classroom Experiment_using-Dictogloss.

Hedge, T. (2000). Teaching and Learning in the Language Classroom. Hong Kong: Oxford University Press.

Hinchey, P. H. (2008). Action Research. New York: Peter Lang Publishing

Husseinali, G. (2011). Using Dictogloss to Advance Proficiency and Accuracy in Teaching Arabic. Retrieved from http://gmu.academia..edu/ ghassanhusseinali/Papers/1160708/Using Dictogloss_to_Advance_Proficiency_and_ Accuracy in Teaching Arabic

Jacobs, G., \& Small, J. (2003). Combing Dictogloss and Cooperative Learning to Promote Language Learning. The Reading Matrix, 3(1), 1-15.

Kidd, R. (1992). Teaching ESL Grammar through Dictation. TESL Canada Journal, 10(1), 49-61.

Le, V. C. (1999). Language and Vietnamese pedagogical contexts. Paper presented at the Fourth International 
Conference on Language and Development, Ha Noi. Retrieved from http://www.languages.ait.ac.th/ hanoi_proceedings/canh.htm

McLafferty, I. (2004). Focus group interviews as a data collecting strategy. Journal of Advanced Nursing, 48(2), 187-194.

Moon, J. (2006). Learning journals: a handbook for reflective practice and professional development. 2nd Ed. New York: Routledge.

Newman, E. (2012). Dare to dictogloss! Teacher Talk blog on AzarGrammar.com. Retrieved from http://azargrammar.com/teacherTalk/blog/2012/01/ dare-to-dictogloss/

Nunan, D. (1997). Listening in Language Learning. The English Centre. Retrieved from http:// jaltpublications.org/tlt/files/97/sep/nunan.html

Price, J. (2001). Action research, pedagogy and change: The transformative potential of action research in pre-service teacher education. Journal of Curriculum Studies, 33(1), 43-74.

Richards, J. C. (2008). Teaching Listening and Speaking.
New York: Cambridge University Press.

Scrivener, J. (2005). Learning teaching: a guidebook for English language teachers. $2^{\text {nd }}$ Ed. Oxford: Macmillan.

Shak, J. (2006). Children using dictogloss to focus on form. Reflections on English language teaching, 5(2), 47-62.

Smith, K. M. (2012). Dictogloss: A Multi-Skill Task for Accuracy in Writing Through Cooperative Learning. Retrieved from http://tht-japan.org/ proceedings/2011/069-080_smith.pdf

Vasiljevic, Z. (2010). Dictogloss as an Interative Mathod of Teaching Listening Comprehension to L2 Learners. English Language Teaching, 3(1), 41-52.

Wanjryb, R. (1990). Grammar Dictation. New York: Oxford University Press.

Webcredible (2006). Focus group - How to run them. Retrieved from http://www.webcredible.co.uk/userfriendly-resources/web-usability/focus-groups.shtml

\title{
ẢNH HƯỞNG CỦA HOẠT ĐộNG NGHE-CHÉP ĐẾN KHẢ NĂNG NGHE HIỂU CỦA SINH VIÊN KHÔNG CHUYÊN TIÊNG ANH
}

\author{
Ngô Thị Minh Hải, Lê Đức Hạnh \\ Khoa tiếng Anh, Đại học Công nghiệp Hà Nội
}

Tóm tắt: Kỹ năng nghe từ lâu đã được xem như một kỹ năng khó đối với cả giáo viên lẫn người học ngoại ngữ. Tuy đã có nhiều nghiên cứu về kỹ năng này nhằm đa dạng các hoạt động trên lớp cũng như làm cho các hoạt động này hiệu quả hơn với người học, song nhu cầu tìm kiếm một hoạt động nghe có cung cấp hoặc củng cố kiến thức ngôn ngữ cần thiết một cách hiệu quả cho việc nghe hiểu vẫn còn cao. Bài báo trình bày một nghiên cứu hành động với 40 sinh viên không chuyên ở trình độ tiền trung cấp với ba công cụ nghiên cứu định tính là phỏng vấn nhóm, nhật ký giáo viên và phân tích bài làm sinh viên nhằm đánh giá ảnh hưởng của hoạt động nghe-chép đến khả năng nghe hiểu và tìm hiểu thái độ của người học ngoại ngữ đối với hoạt động này. Kết quả thu được cho thấy hoạt động nghe-chép đã giúp sinh viên nghe hiểu tốt hơn thông qua việc kích hoạt và nâng cao nhận thức của người học về kiến thức ngôn ngữ, đồng thời cung cấp ngữ cảnh rõ ràng cho hoạt động nghe, qua đó làm cho người học cảm thấy hứng thú hơn với hoạt động này.

Tù khóa: nghiên cứu hành động, hoạt động nghe-chép, kỹ năng nghe, kiến thức ngôn ngữ 